\title{
ASSOCIATION OF QT INTERVAL INDICES WITH CARDIAC AUTONOMIC NEUROPATHY IN DIABETIC PATIENTS
}

\author{
Kumar S. https://orcid.org/0000-0002-9113-3428 \\ Kodidala S.R. https://orcid.org/0000-0001-7830-7211
}

Zydus Medical College and Hospital, Dahod, Gujarat, India

satyanath3218@outlook.com

\begin{abstract}
Relevance. Cardiovascular autonomic neuropathy (CAN) is a severely debilitating yet underdiagnosed condition in patients with diabetes. The prevalence can range from $2.5 \%$ (based on the primary prevention cohort in the Diabetes Control and Complications Trial) to as high as $90 \%$ of diabetic patients. Clinical manifestations range from orthostasis to myocardial infarction. The diagnosis is made using multiple autonomic function tests to assess both sympathetic and parasympathetic function.

Objective: this study was conducted to assess the relationship between Cardiac autonomic neuropathy and QT interval.

Methods. Cross sectional study was conducted in 100 patients attending tertiary care hospital. Deep breathing test, Valsalva ratio, immediate heart rate response to standing 30:15, B.P rise with sustained hand grip and postural hypotension. Scoring was done for cardiac autonomic neuropathy. QT interval and QTc interval were determined and association with CAN was obtained.

Results. Out of 100 type- 2 diabetic patients, $60 \%$ were males and $40 \%$ females. 25 patients having no cardiac autonomic neuropathy and had no prolonged QTc interval. While, 75 patients had QTc prolonged were associated with early and severe CAN cardiac autonomic neuropathy. The prolonged QTc was significantly associated with CAN in diabetic patients when compared without-CAN and controls $(\mathrm{P}<0001)$.

Conclusion. Diabetic cardiac autonomic neuropathy is associated with increase in prolongation of QTc intervals. Hence there is need for regular checkup of autonomic nervous system in diabetic patient to prevent further complications.
\end{abstract}

Keywords: Type- 2 Diabetes, Cardiac autonomic neuropathy, ECG, QTc interval.

Relevance. Diabetes-associated cardiovascular autonomic neuropathy (CAN) damages autonomic nerve fibers that innervate the heart and blood vessels, results in causing abnormalities in heart rate and vascular dynamics. It is well known fact that affect multiple organ systems and is a major cause of morbidity and mortality in patients with diabetes [1]. An association between cardiac autonomic neuropathy and QT interval prolongation was shown in many previous studies and it may predispose to sudden death in diabetes due to cardiac death or myocardial ischemia $[2,3]$. CAN treatment is a complex process which includes modification in lifestyle, exercise. Most of the existing data regarding QT interval and diabetic CAN are in type-1 diabetes while only few studies in type 2 diabetes $[4,5]$. The main causes of QTc prolongation are long-term diabetes, ischemic heart disease, and autonomic system insufficiency; with less frequency, etiologies such as water and electrolyte imbalance which is associated with CAN and Diabetes [6, 7].

Objective: the present study aimed to find out the relationship of corrected QT (QTc) interval and QTc dispersion with diabetic cardiac autonomic neuropathy in type 2 diabetes so that we can identify a subset of diabetic patients who are at high risk for sudden cardiac death.

\section{MATERIALS AND METHODS}

This cross sectional study was conducted on 100 patients of type- 2 diabetes admitted in in patient ward of tertiary care hospital from January 2019 to March 2020.
Ethical clearance was taken from IEC and informed consent was taken from all the participants.

Inclusion Criteria. Type-2 diabetes mellitus and having symptoms of autonomic neuropathy like, postural dizziness, impotence, gustatory sweating, atonic urinary bladder, gastroparesis, neuropathy, tingling sensation, hyperaesthesia and numbness. Cases with evidences of heart diseases, electrolyte imbalance, abnormal resting ECGs, taking drugs known to interfere with autonomic function tests were excluded.

Cardiac dysautonomia was assessed by cardiovascular response to five noninvasive autonomic function tests as recommended by Ewing's et al. [8]. These include: Valsalva ratio: (heart rate response to Valsalva maneuver), deep breath test, 30:15 ratio (immediate heart rate response to standing), postural hypotension (blood pressure response to standing) and SHGT (Blood pressure response to sustained handgrip). Scoring was done as per criteria advocated by Bellavere et al., and Lahotia et al. [9, 10]. A score of 2 or more denoted definite cardiac autonomic neuropathy.

The patients who had definite cardiac autonomic neuropathy were subjected to resting ECG and QT interval; $\mathrm{R}-\mathrm{R}$ interval calculated and the QTc were determinate. The QTc was calculated based on Bazett's formula; QTc=Q$\mathrm{T} / \sqrt{\mathrm{R}-\mathrm{R}}$ and a value exceeding $440 \mathrm{msec}$ was considered prolonged. Fifty healthy volunteers were also subjected to resting ECG and their mean QTc remained below 440 msec.

Statistical Analysis. Data was entered in Ms-Word and expressed in numbers. Analysis of data was done by 
Kumar S.

SPSS-23 latest version. Students t- test were applied to test the significance.

\section{RESULTS AND DISCUSSION}

Hundred cases of type-2 incidence of cardiac autonomic neuropathy (CAN). As evident from table 1, most of the patients $39 \%$ belonged to age group between $41-50$ years, $41 \%$ belonged to age group between 51-60 years and $20 \%$ belonged to age group between $61-70$ years. In this, study 61 cases were males and 39 cases were females given in table- 1 .

Table 1

\section{Age wise distribution of diabetic cases}

\begin{tabular}{|c|c|c|c|}
\hline \multirow{2}{*}{$\begin{array}{c}\text { Age Group } \\
\text { (years) }\end{array}$} & \multicolumn{3}{|c|}{ No. of cases } \\
\cline { 2 - 4 } & Male (n) & Female (n) & Total (n) \\
\hline $41-50$ & 26 & 13 & 39 \\
\hline $51-60$ & 23 & 18 & 41 \\
\hline $61-70$ & 12 & 8 & 20 \\
\hline Total & 61 & 39 & 100 \\
\hline
\end{tabular}

Besides, most of the patients (14\%) had duration of $<5$ years $(70 \%)$ had duration of $5-10$ years $(16 \%)$ had duration of $>10$ years (table 2 ).
Table 2

Duration of diabetes and symptoms of Autonomic Neuropathy

\begin{tabular}{|c|c|c|}
\hline \multirow{2}{*}{ Duration of years } & \multicolumn{2}{|c|}{ No. of cases } \\
\cline { 2 - 3 } & Male (n) & Female (n) \\
\hline$<5$ years & 9 & 5 \\
\hline $5-10$ years & 46 & 24 \\
\hline$>10$ years & 7 & 9 \\
\hline \multicolumn{3}{|c|}{ Symptoms } \\
\hline Postural dizziness & 30 & 22 \\
\hline Impotence/Infertility & 17 & 13 \\
\hline Gustatory sweating & 14 & 12 \\
\hline Atonic urinary bladder & 8 & 7 \\
\hline Gastroparesis & 7 & 5 \\
\hline Constipation & 7 & 7 \\
\hline Diabetic diarrhea & 5 & 5 \\
\hline
\end{tabular}

Regarding the symptoms of autonomic neuropathy, postural dizziness (52\%) was most common symptom in males next common symptom was impotence $(17 \%)$ and infertility in females was (13\%), while diarrhea $(10 \%)$ was the least common symptom (table 3).

Cardiac autonomic tests in diabetic patients

\begin{tabular}{|c|c|c|c|c|c|c|}
\hline \multirow{2}{*}{ Sr.No } & \multirow{2}{*}{\multicolumn{2}{|c|}{ Test characteristics }} & \multirow{2}{*}{ Score } & \multirow{2}{*}{ No. of cases } & \multicolumn{2}{|c|}{ Percentage (\%) } \\
\hline & & & & & Male & Female \\
\hline \multicolumn{7}{|c|}{ Valsalva ratio } \\
\hline 1 & \multirow{3}{*}{ Fall in diastolic BP (mmHg) } & $>1.21$ & 0 & 38 & 46 & 54 \\
\hline 2 & & $1.11-1.20$ & 1 & 42 & 48 & 52 \\
\hline 3 & & $<1.10$ & 2 & 20 & 51 & 49 \\
\hline \multicolumn{7}{|c|}{ Deep breath test } \\
\hline 1 & \multirow{3}{*}{ E:I Ratio (beat/min) } & $>15$ & 0 & 25 & 55 & 45 \\
\hline 2 & & $11-15$ & 1 & 35 & 60 & 40 \\
\hline 3 & & $<10$ & 2 & 40 & 40 & 60 \\
\hline \multicolumn{7}{|c|}{$30: 15$ beat ratio } \\
\hline 1 & \multirow{3}{*}{$30: 15$ ratio } & $>1.04$ & 0 & 20 & 62 & 38 \\
\hline 2 & & $1.01-1.03$ & 1 & 30 & 61 & 39 \\
\hline 3 & & $<1.0$ & 2 & 50 & 70 & 30 \\
\hline \multicolumn{7}{|c|}{ Postural hypotension } \\
\hline 1 & \multirow{3}{*}{ Fall in diastolic BP $(\mathrm{mm} \mathrm{Hg})$} & $<10$ & 0 & 65 & 70 & 30 \\
\hline 2 & & $11-29$ & 1 & 20 & 65 & 35 \\
\hline 3 & & $>30$ & 2 & 15 & 63 & 37 \\
\hline \multicolumn{7}{|c|}{ SHGT (blood pressure response to sustain hand grip) } \\
\hline 1 & \multirow{3}{*}{ Fall in diastolic $\mathrm{BP}(\mathrm{mm} \mathrm{Hg})$} & $>16$ & 0 & 75 & 68 & 32 \\
\hline 2 & & $11-15$ & 1 & 15 & 56 & 44 \\
\hline 3 & & $<10$ & 2 & 10 & 60 & 40 \\
\hline
\end{tabular}


As evident from table 3, Valsalva ratio, deep breath test, 30:15 beat ratio, postural hypotension test and SHGT were abnormal. The grading score for CAD showed that $75 \%$ cases were having score $>2$ were $25 \%$ of cases had score $<2$. Out of 75 patients 44 were between score $2-4$ and 31 were above score 4 mentioned in table- 4 .

Table 4

Scoring of cardiac autonomic neuropathy

\begin{tabular}{|c|c|c|c|}
\hline \multicolumn{4}{|c|}{ Scoring of CAD } \\
\hline \multirow{2}{*}{ Score } & $\begin{array}{c}\text { No } \\
\text { of cases }\end{array}$ & Male & Female \\
\cline { 3 - 4 } & 25 & 52 & 48 \\
\hline 0-1 (No autonomic neuropathy) & 44 & 53 & 47 \\
\hline 2-4 (early autonomic neuropathy) & 41 & 49 & 51 \\
\hline$>5$ (severe autonomic neuropathy) & 31 &
\end{tabular}

QTc interval in diabetic patients were given in table-5.

Table 5

QTe interval in diabetic patients

\begin{tabular}{|c|c|c|c|}
\hline $\begin{array}{c}\text { The duration } \\
\text { of the interval }\end{array}$ & $\begin{array}{c}\text { Male } \\
\text { (n) }\end{array}$ & $\begin{array}{c}\text { Female } \\
\text { (n) }\end{array}$ & $\begin{array}{c}\text { Total } \\
\text { (n) }\end{array}$ \\
\hline$<440(\mathrm{msec})$ & 40 & 23 & 63 \\
\hline$>440(\mathrm{msec})$ & 21 & 16 & 37 \\
\hline Total $(\mathrm{n})$ & 61 & 39 & 100 \\
\hline
\end{tabular}

Association of CAD and QTc interval in diabetic patients were done in table-6. There was a significant association between QTc and diabetis was found when compared CAN with non CAN and controls.

Diabetic CAN is most common in chronic complication in diabetic patients. 100 diabetic patients were assessed cardiac autonomic neuropathy (CAN) and establish the relationship between CAN and QTc interval. Out of the 100 patients studied, the majority of the patients i.e., $39 \%$ belonged to age group $41-50$ years, $41 \%$ belonged to age group 51-60 years and 20\% belonged to age group 61-70 years. Out of the 100 patients, 39 patients were females and 61 were males. The majority $71 \%$ of patients had diabetes of 5-10 years duration, $16 \%$ of patients had diabetes of $>10$ years duration and $14 \%$ of patients had diabetes of $<5$ years duration. In Bathwal et al. [11] study, the mean duration of diabetes was 6.5 years. $19(38 \%)$ patients had nephropathy (as indicated by urine albumin) and these patients were having duration of diabetes of $>7$ years. Thus there is direct relationship of nephropathy with the duration of diabetes. QTc is prolonged in majority of cases (14 out of 19 cases), who had nephropathy.
Valsalva Ratio. $20 \%$ of cases had an abnormal response (i.e. <1.10). Previous studies by Ewing's [12], Bathwal et al. [11] and Lakhotia et al. [10] had abnormal response of $26 \%, 22.3 \%$ and $20 \%$, respectively.

Deep Breath Test. 20\% patient had abnormal response in this study. In Ewing's study [12], it was 42\%, Bathwal et al. [11], it was 38.3\% and in Lakhotia et al. [10], the abnormal response was $42 \%$ abnormal with $20 \%$ borderline cases.

30:15 Ratio. Our study had $42 \%$ cases with abnormal response in this study. In Ewing's study [12], it was $38 \%$ abnormal cases, In Bathwal et al. [11] it had 17\% abnormal cases, where as in another study it was $42 \%$ abnormal with $2 \%$ border line cases [10].

Postural Hypotension. This study had 15\% cases with abnormal response. In Ewing study [12] it was 16\% abnormal cases and in Bathwal et al. study [11], it was 4.4\% abnormal cases and in Lakhotia et al., study [10], it was $16 \%$ abnormal.

SGHT. $10 \%$ cases had an abnormal response in this study. In Ewing's study [12], it was 14\% abnormal cases and in Barthwal et al. studies [11] it was $14.9 \%$ and in Lakhotia et al. studies [10] it was 26\% abnormal cases. Previous studies by Ewing's [12] and Barthwal et al. [11] had not mentioned the borderline cases, however Lakhotia et al. study [10] had stated about borderline cases. Our study had higher score when compared to Lakhotia et al. study [10], it might be due to less sample size in their study.

Our study shows that the abnormal result for deep breath test was highest among other tests, which was also corroborated with the previous studies [10-12]. The 30:15 ratio and Valsalva ratio stood 2 nd and 3rd position respectively, while the postural hypotension and SHGT are less commonly affected. This clearly demonstrates that the development of autonomic neuropathy typically involves the parasympathetic fibers before the sympathetic nerve fibers $[13,14]$. Our study shows that 25 patients had no CAN with no QTc prolongation, these patients had average duration of type 2 DM between 5-6 years.

Further, patients having early and chronic CAN had QTc prolongations in the range of $>440$. Hence it strongly indicates that severity of cardiac autonomic neuropathy and QTc prolongation appears to have a relationship with duration of type-2 diabetes mellitus.

Based on our findings, QTc prolongation was noticed in cardiac autonomic neuropathy also by many other investigators $[15,16]$. QTc has been clearly established as

Table 6

Relation between QTc interval and diabetic autonomic neuropathy

\begin{tabular}{|c|c|c|c|}
\hline Indicator & $\begin{array}{c}\text { Diabetics with autonomic } \\
\text { neuropathy (n=75) }\end{array}$ & $\begin{array}{c}\text { Diabetics without autonomic } \\
\text { neuropathy (n=25) }\end{array}$ & $\begin{array}{c}\text { Control } \\
(\mathbf{n}=\mathbf{5 0})\end{array}$ \\
\hline QTc (mscec) & $418 \pm 26$ & $394 \pm 21^{*}$ & $372 \pm 15^{*}$ \\
\hline
\end{tabular}

Note: $*$ - indicates significant $P$-value $<0.0001$ 
Kumar S.

a predictor of sudden cardiac death. So diabetic patients should be screened for cardiac autonomic neuropathy regularly and those with abnormal QTc should be closely monitored. Hence, there is a strong need for earlier and regular evaluation of autonomic nervous system in type 2 diabetics to prevent further complications [17]. The study has shown that QTc prolongation is an easy and reliable testing method for diabetic cardiac autonomic failure and enables routine measurements for physicians in clinical practice. The data from the current study demonstrated that diabetics had cardiac sympathetic and cardiac parasympathetic nervous system involvement. The presence of symptoms and the involvement of the autonomic nervous system suggest that autonomic dysfunction depends on the duration of diabetics.

\section{CONCLUSION}

CAN the results of the investigation indicate there was prolongation of QTc in type-2 diabetic patients with different degree of CAN. Further research on a large sample size is required to further elucidate the findings of this study and effectiveness of QTc prolongation may be taken as a direct evidence of cardiac autonomic neuropathy in diabetics. The prevalence of CAN in Diabetes is high.

Study limitation. The study have limitations of small populations which can be extended with larger population. Study did not include clinical follow-up on cardiac mortality of patients.

Competing interests. The authors declare no competing interests.

\section{REFERENCE}

1. Khandoker AH, Jelinek HF, Palaniswami M. Identifying diabetic patients with cardiac autonomic neuropathy by heart rate complexity analysis. Biomed Eng Online. 2009; 8:3. DOI: 10.1186/1475-925X-8-3.

View at:

Publisher Site: https://biomedical-engineering-online. biomedcentral.com/articles/10.1186/1475-925X-8-3

PubMed: https://pubmed.ncbi.nlm.nih.gov/19178728/

PubMed Central: https://www.ncbi.nlm.nih.gov/pmc/ articles/PMC2645418/

2. Flügelman MY, Kanter Y, Abinader EG, Lewis BS, Barzilai D. Electrocardiographic patterns in diabetics without clinical ischemic heart disease. Isr J Med Sci. 1983 Mar;19(3):252-5.

View at:

PubMed: https://pubmed.ncbi.nlm.nih.gov/6853122/

3. Kahn JK, Sisson JC, Vinik AI. QT interval prolongation and sudden cardiac death in diabetic autonomic neuropathy. J Clin Endocrinol Metab. 1987 ;64(4):751-4. DOI: 10.1210/jcem-64-4-751

View at:

Publisher Site: https://academic.oup.com/jcem/article-abstract/64/4/751/2653795?redirectedFrom=fulltext
PubMed: https://pubmed.ncbi.nlm.nih.gov/3818902/

4. Takebayashi K, Aso Y, Sugita R, Takemura Y, Inukai T. Clinical usefulness of corrected QT intervals in diabetic autonomic neuropathy in patients with type 2 diabetes. Diabetes Metab. 2002;28(2):127-32

View at:

PubMed: https://pubmed.ncbi.nlm.nih.gov/11976564/

5. Bellavere F, Ferri M, Guarini L, Bax G, Piccoli A, Cardone C, Fedele D. Prolonged QT period in diabetic autonomic neuropathy: a possible role in sudden cardiac death? Br Heart J. 1988; 59(3): 379-383. DOI:10.1136/HRT.59.3.379

View at:

Publisher Site: https://heart.bmj.com/content/59/3/379

PubMed: https://pubmed.ncbi.nlm.nih.gov/3355728/

PubMed Central: https://www.ncbi.nlm.nih.gov/pmc/ articles/PMC1216474/

6. Pillai JN, Madhavan S. Cardiac Autonomic Neuropathy and QTc Interval in Type 2 Diabetes. Heart India. 2015;3(1):8-11. DOI: 10.4103/2321-449X.153279

View at:

Publisher Site: https://www.heartindia.net/article. asp? issn=2321-449x; year $=2015$; volume $=3$; issue $=1$; spage $=8$; epage $=11$; aulast $=$ Pillai

7. Astrup AS, Tarnow L, Rossing P, Hansen BV, Hilsted J, Parving HH. Cardiac autonomic neuropathy predicts cardiovascular morbidity and mortality in TYPE 1 diabetics patients with diabetic nephropathy. Diabetes care. 2006; 29(2):334-9. DOI: $10.2337 / \mathrm{di}-$ acare.29.02.06.dc05-1242

View at:

Publisher Site: https://diabetesjournals.org/care/article/29/2/334/26243/ Cardiac-Autonomic-Neuropathy-Predicts

PubMed: https://pubmed.ncbi.nlm.nih.gov/16443883/

8. Ewing DJ, Campbell IW, Clark BF. The natural history of diabetic autonomic neuropathy. QJ Med. 1980; 49(193):95-108.

View at:

PubMed: https://pubmed.ncbi.nlm.nih.gov/7433630/

9. Bellavere F, Bosello G, Fedele D, Cardone C, Ferri M. Diagnosis and Management of diabetic autonomic neuropathy. Br. Med. J. (Clin Res Ed). 1983; 287(6384):61. DOI: $10.1136 / \mathrm{bmj} .287 .6384 .61-\mathrm{a}$.

View at:

Publisher Site: https://www.bmj.com/ content/287/6384/61.2

PubMed: https://pubmed.ncbi.nlm.nih.gov/6407693/ PubMed Central: https://www.ncbi.nlm.nih.gov/pmc/ articles/PMC1548146/

10. Lakhotia M, Shah PK, Vyas R, Jain SS, Yadav A, Parihar MK. Clinical dysautonomia in DM - a study with seven autonomic reflex function test. J Assoc Physicians India. 1997;45(4):271-274.

View at:

PubMed: https://pubmed.ncbi.nlm.nih.gov/12521082/ 
11. Bathwal S.P. QTc prolongation is diabetes mellitus an indicator of Cardiac autonomic neuropathy. J Assoc Physicians India. 1997;45(1):15-17.

12. Ewing DJ, Campbell IW, Clarke BF. Assessment of cardiovascular effects in diabetic autonomic neuropathy and prognostic implications. Ann Intern Med. 1980; 92(2 Pt 2):308-11. DOI: 10.7326/0003-4819-92-2-308. View at:

Publisher Site: https://www.acpjournals.org/ doi/10.7326/0003-4819-92-2-308

PubMed: https://pubmed.ncbi.nlm.nih.gov/7356219/

13. Sucharita S, Bantwal G, Idiculla J, Ayyar V, Vaz M. Autonomic nervous system function in type 2 diabetes using conventional clinical autonomic tests, heart rate and blood pressure variability measures. Indian J Endocrinol Metab. 2011; 15(3): 198-203. DOI: $10.4103 / 2230-8210.83406$

View at:

Publisher Site: https://journals.lww.com/indjem/Pages/default.aspx

PubMed: https://pubmed.ncbi.nlm.nih.gov/21897898/ PubMed Central: https:/www.ncbi.nlm.nih.gov/pmc/ articles/PMC3156541/

14. Hong J, Liu W-Y, Hu X, Jiang F-F, Xu Z-R, Li F, Shen F-X, Zhu H. Association between heart rate-corrected QT interval and severe peripheral arterial disease in patients with type 2 diabetes and foot ulcers. Endocrine connections. $2021 \mathrm{Jul} ; 10,8$ 845-851. DOI:10.1530/EC-21-0140

View at:

Publisher Site: https://ec.bioscientifica.com/view/journals/ec/10/8/EC-21-0140.xml

PubMed: https://pubmed.ncbi.nlm.nih.gov/34223825/

PubMed Central: https://www.ncbi.nlm.nih.gov/pmc/ articles/PMC8346192/
15. Pappachan JM, Sebastian J, Bino BC, Jayaprakash K, Vijayakumar K, Sujathan P, Adinegara LA. Cardiac autonomic neuropathy in diabetes mellitus: prevalence, risk factors and utility of corrected QT interval in the ECG for its diagnosis. Postgrad Med J. 2008; 84(990):205-210. DOI:10.1136/pgmj.2007.064048 View at:

Publisher Site: https://pmj.bmj.com/ content/84/990/205

PubMed: https://pubmed.ncbi.nlm.nih.gov/18424578/

16. Dimitropoulos G, Tahrani AA, Stevens MJ. Cardiac autonomic neuropathy in patients with diabetes mellitus. World J Diabetes. 2014 Feb 15; 5(1):17-39. DOI: 10.4239/wjd.v5.i1.17

View at:

Publisher Site: https:/www.wjgnet.com/1948-9358/ full/v5/i1/17.htm

PubMed: https://pubmed.ncbi.nlm.nih.gov/24567799/ PubMed Central: https://www.ncbi.nlm.nih.gov/pmc/ articles/PMC3932425/

17. Ogurtsova K, da Rocha Fernandes JD, Huang Y, Linnenkamp U, Guariguata L, Cho NH, Cavan D, Shaw JE, Makaroff LE. IDF Diabetes Atlas: Global estimates for the prevalence of diabetes for 2015 and 2040. Diabetes Res Clin Pract. 2017; 128:40-50. DOI: 10.1016/j.diabres.2017.03.024

View at:

Publisher Site: https://www.diabetesresearchclinicalpractice.com/article/S0168-8227(17)30375-3/fulltext PubMed: https://pubmed.ncbi.nlm.nih.gov/28437734/

Article history: Received: 15.12.2021 Revision requested: 18.12 .2021 Revision received: 20.12.2021 Accepted: 23.12.2021 Published: 30.12 .2021

\title{
ЗВ'ЯЗОК ПОКАЗНИКІВ ІНТЕРВАЛУ QТ З СЕРЦЕВО-СУДИННОЮ ВЕГЕТАТИВНОЮ НЕЙРОПАТІЕЮ У ХВОРИХ НА ЦУКРОВИЙ ДІАБЕТ
}

\author{
Кумар С., Кодідала С.P. \\ Медичний коледж та клініка Зідуса, Даход, итат Гуджарат, Індія
}

satyanath3218@outlook.com

\footnotetext{
Актуальність. Серцево-судинна вегетативна нейропатія (СВ) є важким виснажливим і мало дослідженим захворюванням у пацієнтів 3 діабетом. Поширеність може варіювати від 2,5\% (на основі даних у групах з первинною профілактикою) до $90 \%$ пацієнтів $з$ діабетом. Клінічні прояви варіюють від ортостазу до інфаркту міокарда. Для діагностики використовуються множинні вегетативні функціональні тести для оцінки функцій як симпатичного, так і парасимпатичного відділів.

Мета: оцінити залежність між проявами серцевої вегетативної нейропатії та показниками інтервалу QT.

Методи. Перехресне дослідження було проведено на 100 пацієнтах, які відвідують лікарню високоспеціалізованої медичної допомоги. Оцінювали прояви серцевої вегетативної нейропатії: тест на глибоке дихання, коефіцієнт Вальсальви, негайну реакцію ЧСС при стоянні 30:15, ступінь підвищення артеріального тиску (з використанням зап’ясного ременя), та постуральну гіпотензію. Проведено кореляцію між тривалістю інтервалу QT та проявами серцевої вегетативної нейропатії у контрольній та досліджуваних групах.

Результати. Зі 100 пацієнтів 3 діабетом 2 типу 60\% становили чоловіки та 40\% жінки. Виявлено 25 пацієнтів без серцевої вегетативної нейропатії та подовженого інтервалу QTс. У той час як у 75 пацієнтів подовження QТс було пов язане 3 ранньою та тяжкою СВН. Подовження інтервалу QТс корелювало з проявами СВН у пацієнтів з діабетом у порівнянні з групою хворих без проявів СВН та контрольної групи $(\mathrm{P}<0001)$.
} 
Висновок. Діабетична кардіальна вегетативна нейропатія асоційована зі збільшенням тривалості інтервалу QTc. Отже, у пацієнтів з діабетом необхідно регулярно проводити функціональні тести для оцінки вегетативної нервової системи, щоб запобігти подальшим ускладненням.

Ключові слова: цукровий діабет 2 типи, вегетативна серцева нейропатія, ЕКГ, інтервал QТс.

\title{
СВЯЗЬ ПОКАЗАТЕЛЕЙ ИНТЕРВАЛА QТ С СЕРДЕЧНО-СОСУДИСТОЙ ВЕГЕТАТИВНОЙ НЕЙРОПАТИЕЙ У БОЛЬНЫХ САХАРНЫМ ДИАБЕТОМ
}

\author{
Кумар С., Кодидала С.P. \\ Медииинский колледж и клиника Зидуса, Даход, итат Гуджарат, Индия \\ satyanath3218@outlook.com
}

\begin{abstract}
Актуальность. Сердечно-сосудистая вегетативная нейропатия (СBH) является тяжелым изнурительным, и мало исследованным заболеванием у пациентов с диабетом. Распространенность может варьировать от 2,5\% (на основе данных в группах с первичной профилактикой) до $90 \%$ пациентов с диабетом. Клинические проявления варьируют от ортостаза до инфаркта миокарда. Для диагностики используются множественные вегетативные функциональные тесты для оценки функций как симпатического, так и парасимпатического отделов.

Цель: оценить зависимость между проявлениями сердечной вегетативной нейропатии и показателями интервала QT.

Методы. Перекрестное исследование было проведено на 100 пациентах, посещающих больницу высокоспециализированной медицинской помощи. Оценивали проявления сердечной вегетативной нейропатии: тест на глубокое дыхание, коэффициент Вальсальвы, немедленную реакция ЧСС при стоянии 30:15, степень повышение АД (с использованием кистевого ремня), и постуральную гипотензию. Проведена корреляция между длительностью интервала QТ и проявлениями сердечной вегетативной нейропатии в контрольной и исследуемых группах.

Результаты. Из 100 пациентов с диабетом 2 типа $60 \%$ составляли мужчины и $40 \%$ женщины. Выявлено 25 пациентов без сердечной вегетативной нейропатии и удлиненного интервала QTc. В то время как у 75 пациентов удлинение QTс было связано c ранней и тяжелой СBН. Удлинение интервала QTс коррелировало с проявлениями СВН у пациентов с диабетом при сравнении с группой больных без проявлений СВН и контрольной группы $(\mathrm{P}<0001)$.

Вывод. Диабетическая кардиальная вегетативная нейропатия ассоциирована с увеличением длительности интервала QTс. Следовательно, у пациентов с диабетом необходимо регулярно проводить функциональные тесты для оценки вегетативной нервной системы, чтобы предотвратить дальнейшие осложнения.
\end{abstract}

Ключевые слова: сахарный диабет 2 типа, вегетативная сердечная нейропатия, ЭКГ, интервал QТс. 